\title{
SURFACE AND SUBSURFACE DRAINAGE EVOLUTION OF THE CORFINO AND SORAGGIO KARST AREAS (TUSCANY, ITALY)
}

\author{
RAZVOJ POVRŠINSKE IN PODZEMNE ODTOČNE MREŽE NA \\ KRAŠKIH OBMOČJIH CORFINO IN SORRAGIO
}

\author{
Giampaolo MARIANNELLI ${ }^{1} \&$ Leonardo PICCINI ${ }^{1}$
}

\begin{abstract}
UDC 551.435.8(450.52)

Giampaolo Mariannelli \& Leonardo Piccini: Surface and subsurface drainage evolution of the Corfino and Soraggio Karst areas (Tuscany, Italy)

The Pania di Corfino and Ripa di Soraggio are two minor karst areas in Tuscany, having a surface of only $11 \mathrm{~km}^{2}$, but contain more than 100 known caves. Some caves are old epi-phreatic passages testifying to a discontinuous lowering of base level in the two major valleys that cross the carbonate outcrops: the Serchio di Soraggio and the Fiume rivers, respectively located along the NW and SE borders of the massif. The spatial-altimetric distribution of major caves, which are found on a vertical range of a few hundreds of meters, and their relationships with the position of surface alluvial deposits have allowed to infer a first evolutionary framework of karst during the late Quaternary. If we refer to a simple model, where fluvial deposition occurs mainly during cold stages and incision during warm stages, the discrete distribution of cave passages suggests that the different epi-phreatic phases are the responses to the alternation of cold and warm periods. In any case, the re-organization of the river network induced by the tectonic uplift had a relevant effect on cave systems. First, the underground diversion of surface drainage enhanced the downcutting of NW and SE peripheral streams, which received a larger quantity of water through karst springs due to the favored morpho-structural setting. Successively, the backward piracy of the allogenic catchments of the karst systems by surface tributaries led to the dewatering of caves and to the present situation.

Keywords: karst, speleogenesis, relict caves, Pania di Corfino, Northern Apennines.
\end{abstract}

\author{
Izvleček \\ UDK 551.435.8(450.52) \\ Giampaolo Mariannelli \& Leonardo Piccini: Razvoj površin- \\ ske in podzemne odtočne mreže na kraških območjih Corfino \\ in Sorragio
}

Pania di Corfino in Ripa di Soraggio sta dva manjša kraška območja v Toskani. Površine območij znašajo $11 \mathrm{~km}^{2}$, vendar je na njih znanih preko 100 jam. Obstoj starih epifreatičnih galerij priča o nezveznem zniževanju nivoja erozijske baze dolin rek Serchio di Soraggion in Fiume, ki sekata karbonatno območje na SZ oziroma JV meji masiva. Glavne jame so razporejene v višinskem obsegu $500 \mathrm{~m}$. Povezava leg jam in položaja aluvialnih sedimentov, nam je omogočila sklepanje o razvoju območja v poznem kvartarju. Če predpostavimo odlaganje fluvialnega gradiva $v$ mrzlih obdobjih in vrezovanje rečnih dolin v toplih obdobjih, lahko sklepamo, da so nezvezno razporejeni epifreatični rovi nastali ob prehodih iz enega $\mathrm{v}$ drugo obdobje. Poleg tega je na razvoj jamskih sistemov vplivala tudi preureditev rečne mreže ob tektonskem dvigu. Strukturnomorfološki pogoji so narekovali razvoj podzemnega odtoka skozi masiv, preko katerega so površinski vodotoki $z$ ene strani masiva napajali vodotoke na drugi strani, ki so se posledično hitreje urezovali. Ves proces je napredoval gorvodno in ustvaril niz starih ponorov, izvirov in pripadajočih fosilnih jamskih galerij.

Ključne besede: kras, speleogeneza, reliktne jame, Pania di Corfino, severni Apenini.

\footnotetext{
${ }^{1}$ Dipartimento di Scienze della Terra, Università degli Studi di Firenze, e-mail: giampaolo.mariannelli@gmail.com; leonardo.piccini@unifi.it
}

Received/Prejeto: 9.9.2010 


\section{INTRODUCTION}

Pania di Corfino and Ripa di Soraggio mountains are located to the east of the famous Apuan Alps karst area (northwestern Tuscany) and represent the widest carbonate outcrops in the northeastern side of the Serchio River basin (Northern Tuscany). This circumstance offers the possibility to get important geomorphological data concerning the evolution of this sector of the tectonic basin,

Tab. 1: Major caves of the Corfino-Soraggio area.

\begin{tabular}{l|l|c|c|c}
\hline $\begin{array}{l}\text { Inventory } \\
\text { num. }\end{array}$ & Name & $\begin{array}{c}\text { Elevation } \\
(\boldsymbol{m})\end{array}$ & $\begin{array}{c}\text { Vertical range } \\
(\boldsymbol{m})\end{array}$ & $\begin{array}{c}\text { Length } \\
(\boldsymbol{m})\end{array}$ \\
\hline $162 \mathrm{~T} / \mathrm{LU}$ & TANA DI MAGNANO & 635 & $-8 ;+13$ & 307 \\
\hline $264 \mathrm{~T} / \mathrm{LU}$ & TANA DELLA GUERRA DI SASSOROSSO & 880 & +7 & 81 \\
\hline $288 \mathrm{~T} / \mathrm{LU}$ & CAVERNA DEL FRATE & 840 & $-6 ;+10$ & 125 \\
\hline $289 \mathrm{~T} / \mathrm{LU}$ & TANA DELLE GRACCHIE DI SASSOROSSO & 878 & -20 & 94 \\
\hline $1572 \mathrm{~T} / \mathrm{LU}$ & ABISSO LUIGIONE & 1325 & -200 & 500 \\
\hline $1766 \mathrm{~T} / \mathrm{LU}$ & TANA DEI PIPISTRELLI & 750 & -5 & 80 \\
\hline $41 \mathrm{~T} / \mathrm{LU}$ & TANA DELLE FATE DI SORAGGIO & 860 & $-6 ;+5$ & 1000 \\
\hline $752 \mathrm{~T} / \mathrm{LU}$ & PORTA DELLA RIPA & 940 & -75 & 1120 \\
\hline $1382 \mathrm{~T} / \mathrm{LU}$ & ANTRO DEL FAUNO & 1100 & $-4 ;+61$ & 342 \\
\hline $1691 \mathrm{~T} / \mathrm{LU}$ & INGHIOTTITOIO DEI CASINI DI CORTE & 1120 & -122 & 173 \\
\hline $1761 \mathrm{~T} / \mathrm{LU}$ & INGHIOTTITOIO DEL RIO RIMONIO & 1074 & -177 & 361 \\
\hline
\end{tabular}

of the remarkable geological interest this area holds for the study of the Northern Apennine orogenesis.

Despite their small extension, Pania di Corfino and Ripa di Soraggio are two of the most interesting karst areas of the Northern Apennines (Quarina 1910). In recent years, the knowledge of karst phenomena has largely increased as the result of the efforts of many speleological groups, particularly the Gruppo Speleologico Paletnologico Gaetano Chierici (GSPGC) of Reggio Emilia (Catellani et al. 1995, 2002). Known caves today number about a hundred (main caves are listed on Tab. 1). Most of them have a small size but they are relict fragments of much larger systems, and their morphological features can provide an evolutionary framework of the karst phenomena.

This paper presents a comparing the fluvial landforms, such as alluvial deposits and paleo-valleys, with the karst systems. Thus, this research goes beyond strict speleological concerns, because first analysis to connect the cave features with the geostructural setting and the morpho-tectonic evolution of this area during the Quaternary.

\section{GEOMORPHIC AND GEOLOGICAL FRAMEWORK}

The study area is part of the Orecchiella Natural Park, in the province of Lucca, and includes the carbonate outcrops of the Ripa di Soraggio to the NW and of the Pania di Corfino to the SE (Fig. 1). These two reliefs form together an $8 \mathrm{~km}$ long and about $2 \mathrm{~km}$ wide, NW-SE ridge.

Ripa di Soraggio $(1320 \mathrm{~m}$ asl) is a minor elevation bounded on three sides by towering scarps that overlook the Serchio di Soraggio valley to the N, the Fosso Barbata valley to the $\mathrm{W}$ and the Rio Rimonio canyon to the NE. The relief displays deep gorges, high scarps and steep slopes; while at the higher elevations there is a wide low-gradient erosional surface (the Ripa and La Bandita), which merges to the arenaceous terrains to the NE.

Pania di Corfino is a $1603 \mathrm{~m}$ high mountain. The western side shows steep trapezoidal slopes facing the village of Corfino, whereas the east side gently rises up to the main Tuscany-Romagna Apennine ridge. A subdued erosional surface, extending between 1350 and
$1420 \mathrm{~m}$ asl, forms the southern part of the relief and is limited to the SE by the deep gorge of the Fiume river, which is about $400 \mathrm{~m}$ entrenched into the limestone formations.

The drainage geometry of the whole area has a rectangular pattern and displays many elbows that can be associated with river captures (Fig. 2). In particular, Fiume a Corte and Rio Rimonio show two evident NNW oriented deviations towards the Serchio di Soraggio. The two streams diverted the old drainage direction captured by a left-side tributary of the Serchio di Soraggio (Mariannelli 2006). Alluvial deposits trace the paleo flow pathway of these two rivers that in the past were directly tributaries of the Serchio River towards the SW. More generally, the occurrence of saddles and relict valleys along the old drainage direction testifies the piracy of the NE (Serchio di Soraggio) and SE (Fiume) peripheral streams in respect of medial streams. Minor captures occur also in the southern portion of Pania di Corfino and 


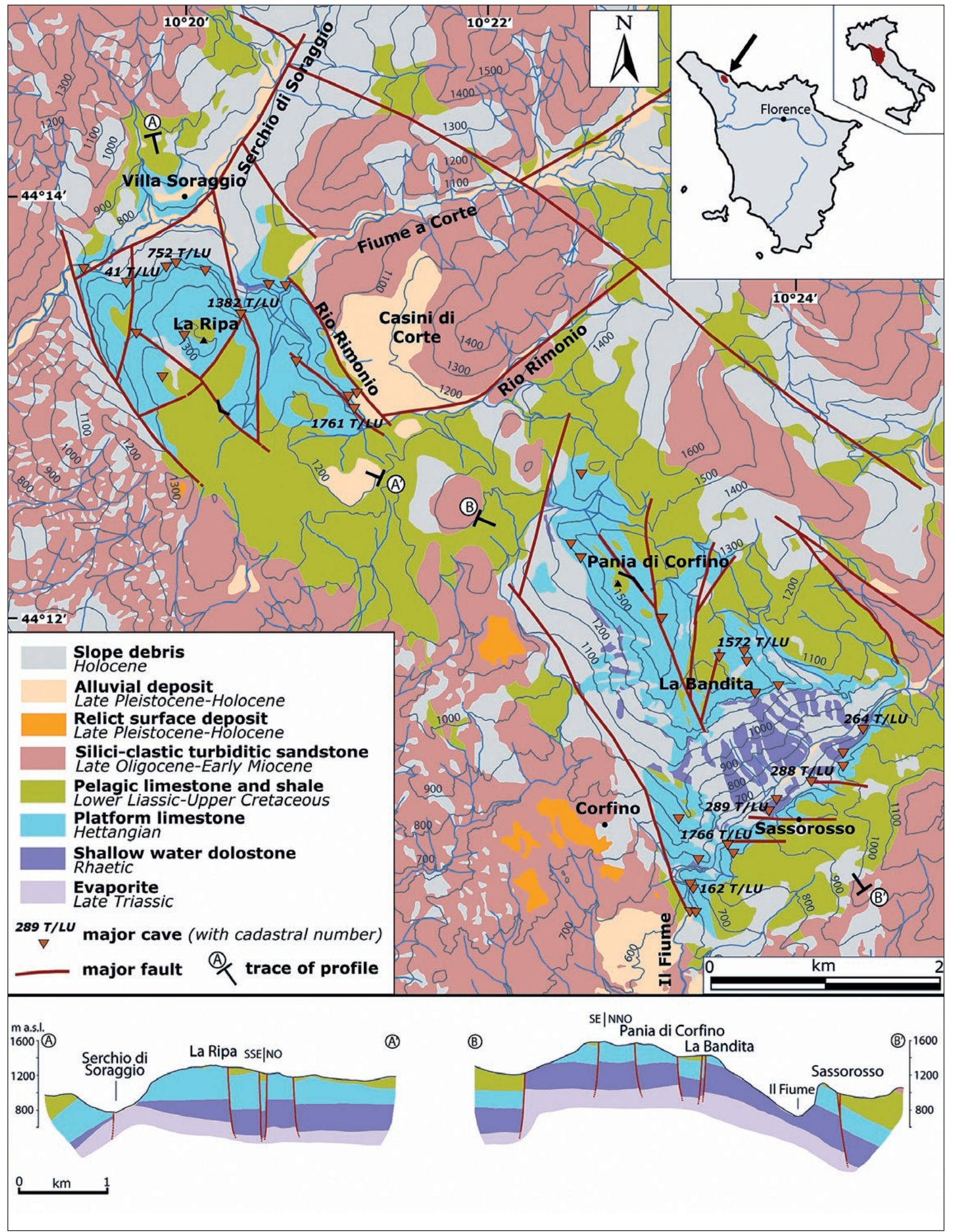

Fig. 1: Geological map and profiles of Ripa di Soraggio and Pania di Corfino karst areas (Geological data simplified from Dallan et al. (1991), modified on the basis of original field surveys). 


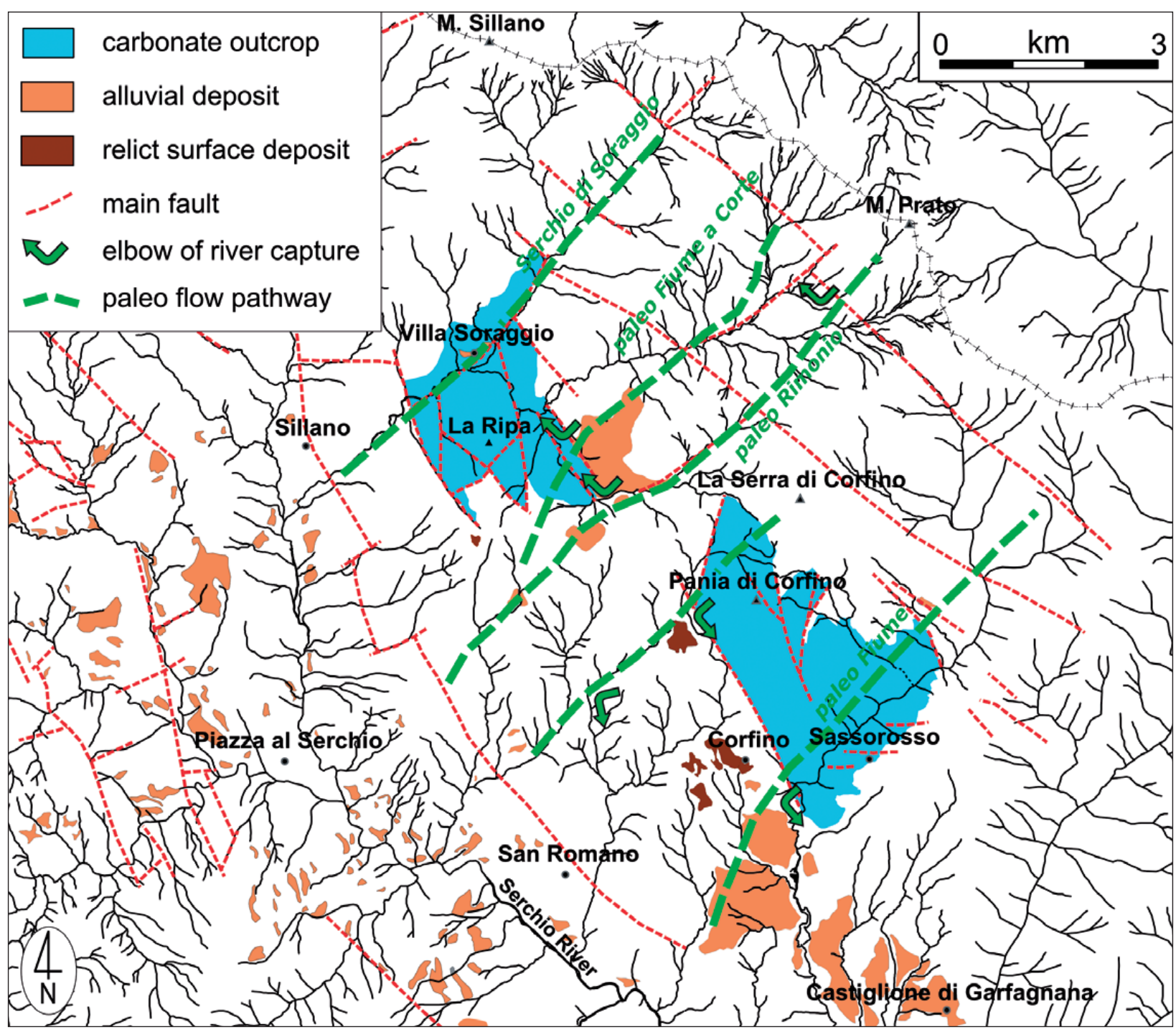

Fig. 2: Paleo-flow pathways and captures of the river network evolution in the Corfino-Soraggio Mesozoic massif and surroundings areas (after Mariannelli 2006, modified).

confirm the rearrangement of the drainage network due to differential incision rate of streams, according to their structural setting or to local tectonic activity (Bartolini \& Fazzuoli 1997).

The Corfino and Soraggio Mesozoic outcrops represent an important geological site of the Northern Apennines, due to the presence of one of the most complete Triassic-Jurassic carbonate sequences of the Tuscan Nappe (Azzaroli 1955; Fazzuoli 1974; Fazzuoli \& Turi 1981; Fazzuoli et al. 1985).

The lower formation consists of Upper Triassic evaporites (Anidriti di Burano), which are overlain through a tectonic contact by dolostone and dolomitic limestone with a maximum thickness of $260 \mathrm{~m}$ (Pania di Corfino Formation: Noric- Raethic). Above, we find $90 \mathrm{~m}$ of dolomitic limestone and marly limestone ( $\mathrm{La}$
Spezia Formation, Raethic). During the Lower Jurassic, the sedimentation of Calcare Massiccio limestone occurred; this formation consists of grey, massive reefal limestone and reaches a thickness of $400 \mathrm{~m}$.

In the NW area, levels of polymictic breccia overlie the Calcare Massiccio with an unconformity surface. In the SE area (Pania di Corfino) a complete sequence takes place, though having a small thickness. Here, the Calcare Massiccio limestone is covered by a pelagic to emipelagic sequence, which consists of: nodular marly limestone rich in ammonites (Rosso Ammonitico, Sinemuriano), cherty limestone (Calcare Selcifero, middle-upper Lias), marls (Marne a Posidonia, Dogger), siliceous deposit (Diaspri, Malm) and a Cretaceous to Oligocene complex made up mainly of shales, marls and calcarenites (Scisti Policromi). 
A more than $2000 \mathrm{~m}$ thick turbiditic deposit ("Macigno" formation sandstones) widely crops out all around the Mesozoic formations, from the pedemontane area (SW) to the main Apennine watershed (NE).

Neogene alluvial sediments are widely spread as suspended deposits, in the highest part of the area, or as recent terraced deposits in the valley bottom. Some of these deposits could be the apical part of Middle-Late Pleistocene alluvial fans, which fed the Serchio Basin.

The Pania di Corfino and Ripa di Soraggio carbonate outcrops form an overturned east-facing fold with a
NW-SE oriented axis, which involves the Mesozoic terrains of the Tuscan succession. Beginning from the Early Pleistocene, extensional tectonics partially dismantled this structure as a result of the uplift of the main Apennine chain and the tectonic collapse of Serchio Basin (Puccinelli et al. 1987; Bartolini 2003; Coltorti et al. 2008 and references therein). Major faults have NW-SE strikes and are part of the step listric system bounding the NE flank of the Serchio River Basin (Dallan et al. 1991). Minor faults, with only a slight dislocation, are SW-NE oriented and control the position of some rivers.

\section{KARST AND CAVE FEATURES}

The Pania di Corfino and Ripa di Soraggio karst areas have a surface of $11 \mathrm{~km}^{2}$ as a whole. Surface karst forms are not well developed. Dolines are concentrated in some restricted flat summit zones and are often covered by soils or rock debris. During the Middle-Late Pleistocene cold stages, the high relief and the regional climatic conditions enhanced the mechanical denudation processes, such as crionival modeling, inhibiting the development of surface karst landforms and forming wide covers of debris.
Caves are mainly developed in the Calcare Massiccio formation. The longest caves are located on the slopes of the two major valleys: the Serchio di Soraggio and the Fiume, respectively at the NW and SE borders of the carbonate massif (see Fig. 1 for cave location).

In the Soraggio area, the most important cave is the Porta della Ripa (cadastre number: 752 T/LU), $1120 \mathrm{~m}$ long and $73 \mathrm{~m}$ deep (Fig. 3). It is a mainly phreatic cave, with horizontal NW-SE oriented conduits up to $10 \mathrm{~m}$ wide. Some parts of these passages are characterized by

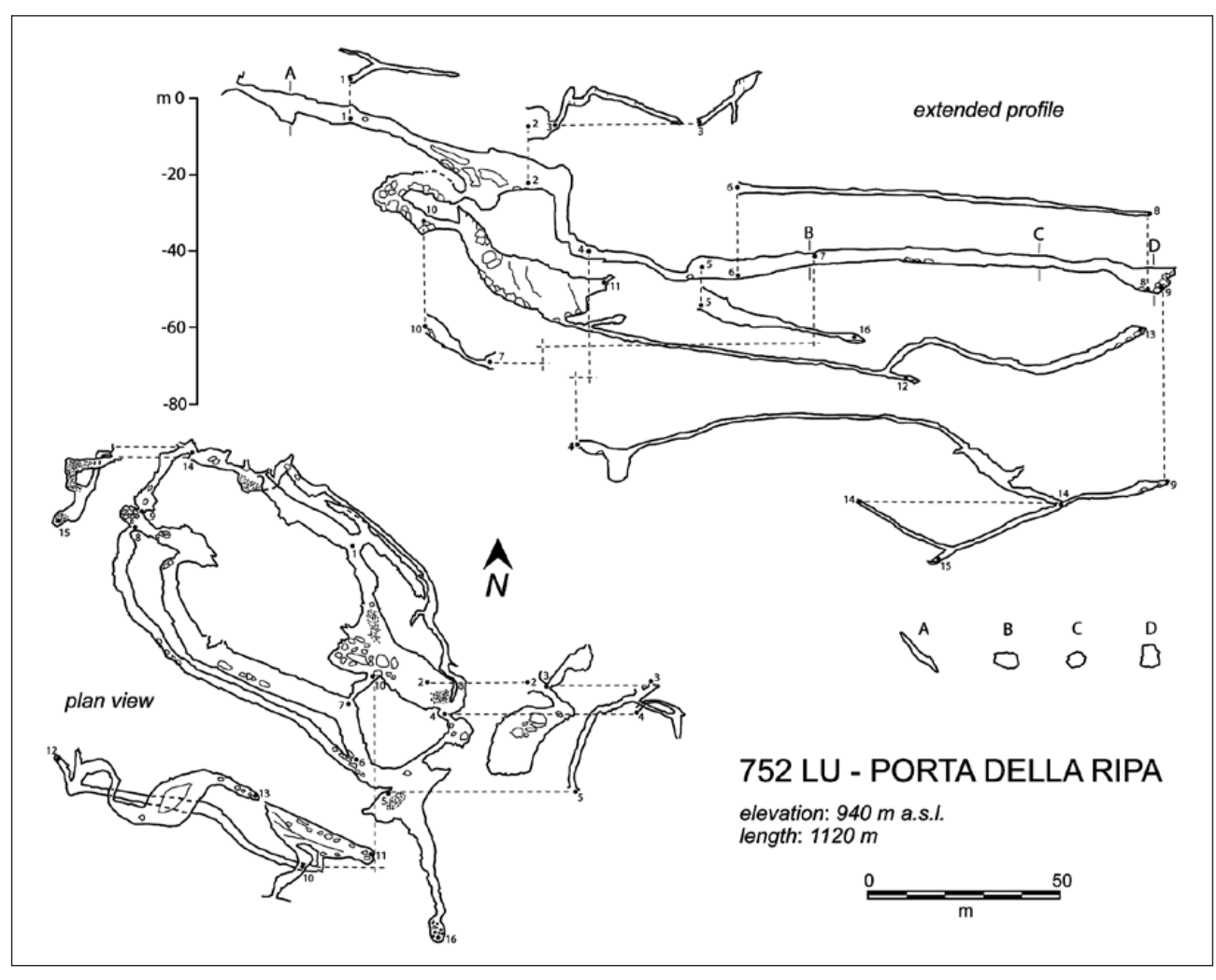

Fig. 3: Porta della Ripa, the longest cave of the area, is a paleo-phreatic cave with a relevant level of large conduits at $900 \mathrm{~m}$ asl (survey by Gruppo Speleologico Paletnologico G. Chierici - Reggio Emilia). 


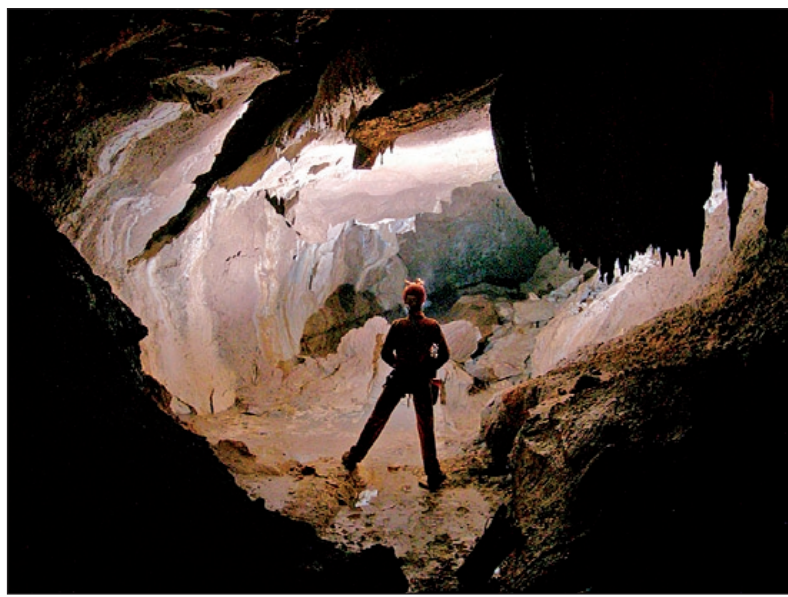

Fig. 4: The main phreatic tube of the Ripa di Soraggio, showing a slight vadose erosion of the floor (Photo: L. Piccini).

vadose entrenchment, but the original phreatic morphology is nearly completely preserved (Fig. 4). Tana delle Fate di Soraggio (41 T/LU) is another important cave, more than $1 \mathrm{~km}$ long, consisting of a maze network of phreatic conduits (Fig. 5), which do not show a significant incision under vadose conditions. At a higher altitude, the Antro del Fauno (1382 T/LU) is a relict cave of epiphreatic origin, situated more than $300 \mathrm{~m}$ above the valley bottom (Fig. 6).

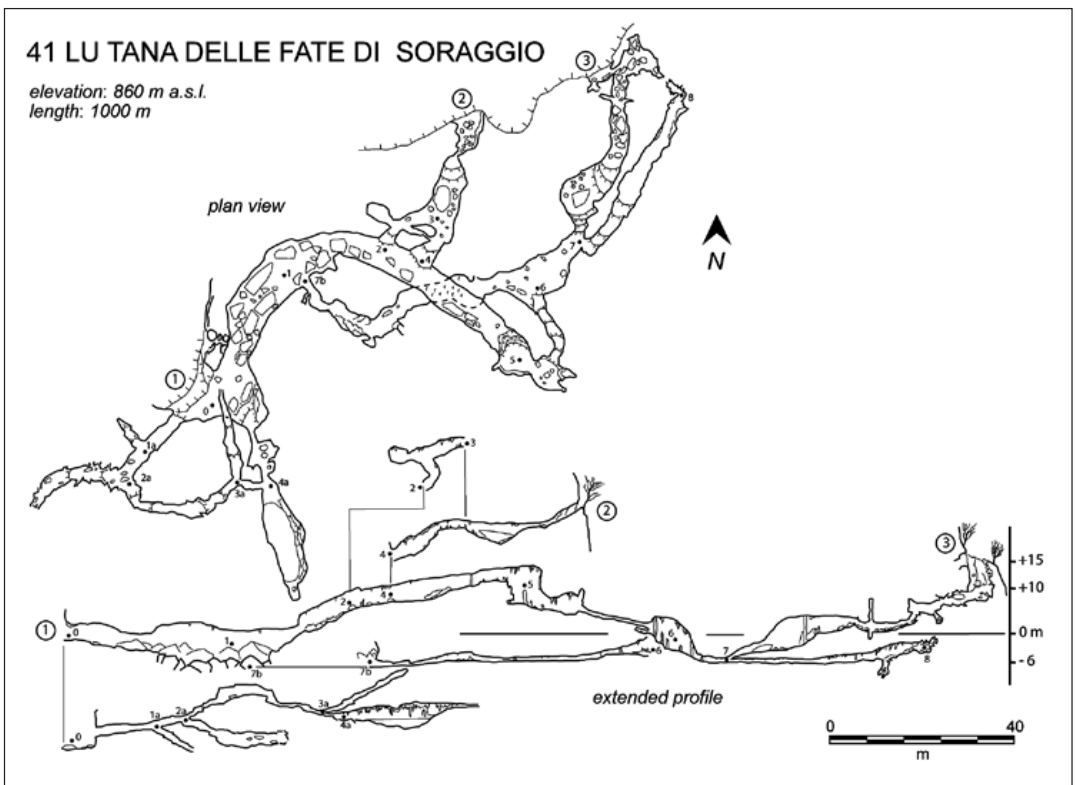

Fig. 5: Tana delle Fate di Soraggio, a segment of a maze phreatic system intercepted by river incision (survey by Gruppo Speleologico Paletnologico G. Chierici - Reggio Emilia).

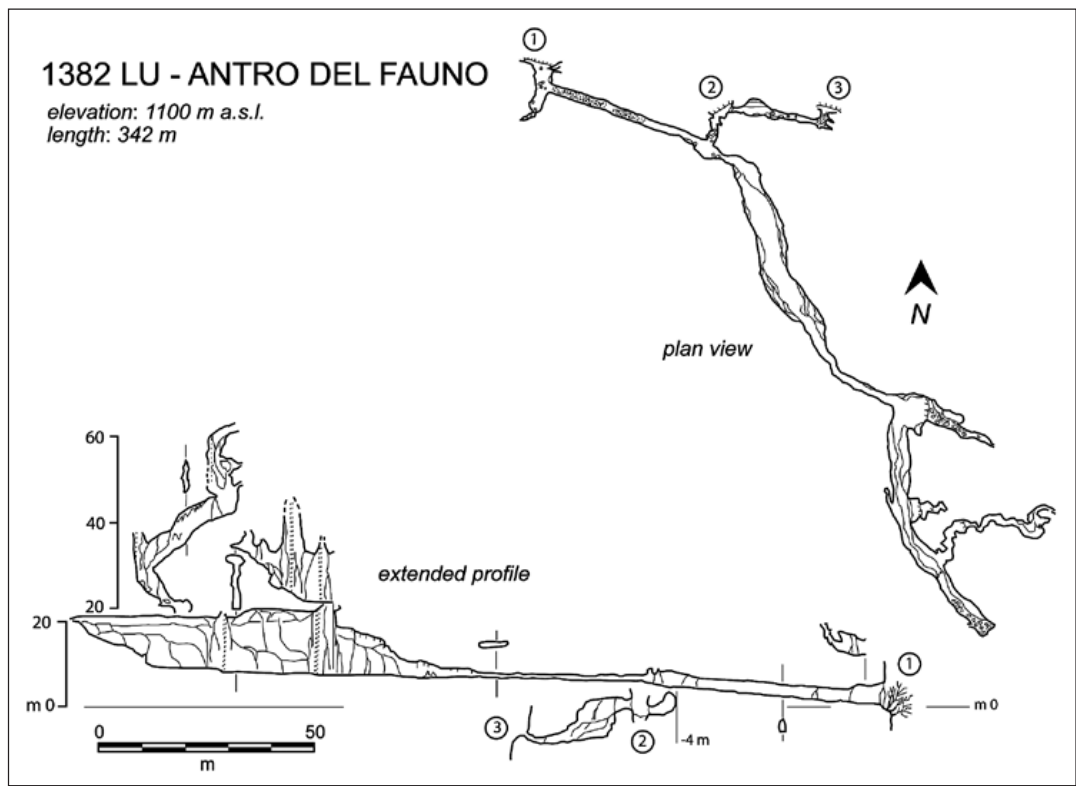

Fig. 6: Antro del Fauno, a relict suspended segment of an epiphreatic cave, on the $N$ wall of Ripa di Soraggio (survey by Gruppo Speleologico Paletnologico G. Chierici - Reggio Emilia). 


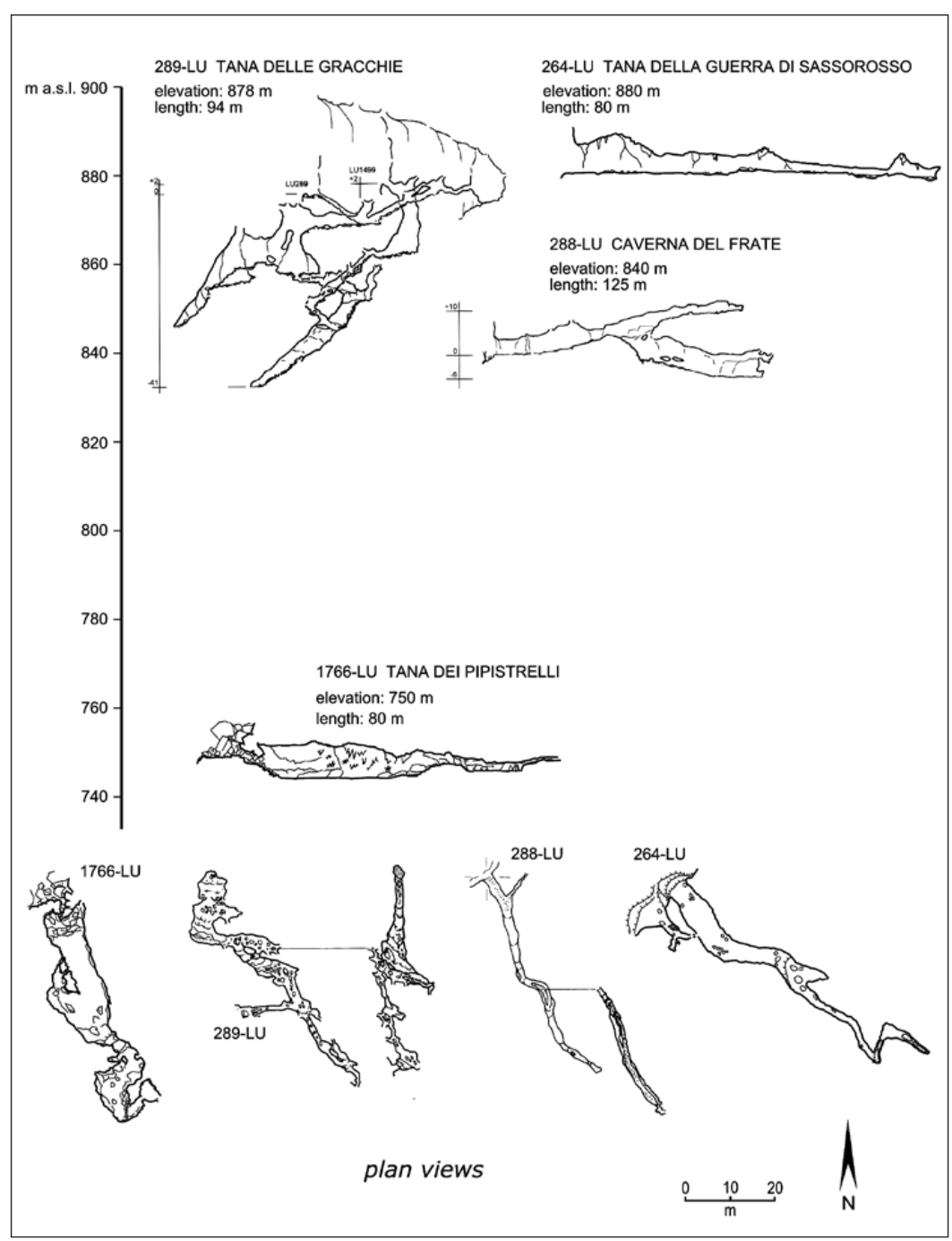

Fig. 7: The four paleo-phreatic caves located in the middle part of the Fiume River canyon (surveys by Gruppo Speleologico Paletnologico G. Chierici - Reggio Emilia and by authors).

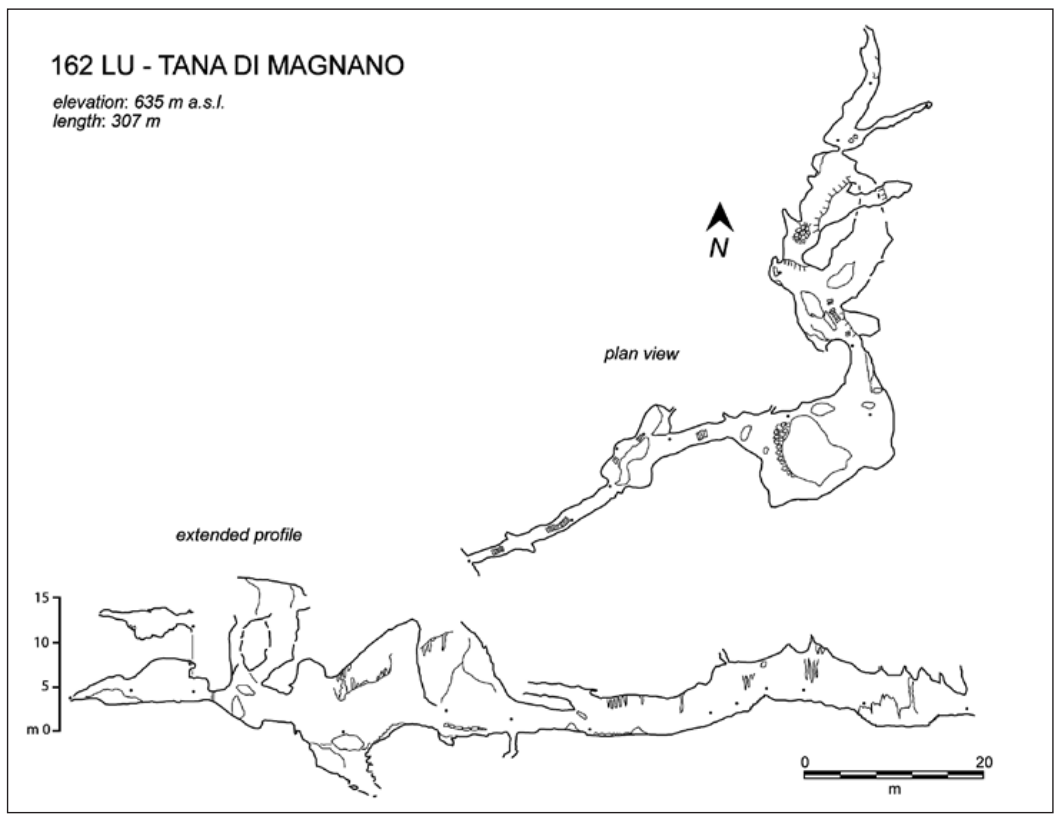

Fig. 8: The Tana di Magnano (survey by Gruppo Speleologico Paletnologico G. Chierici-Reggio Emilia). 


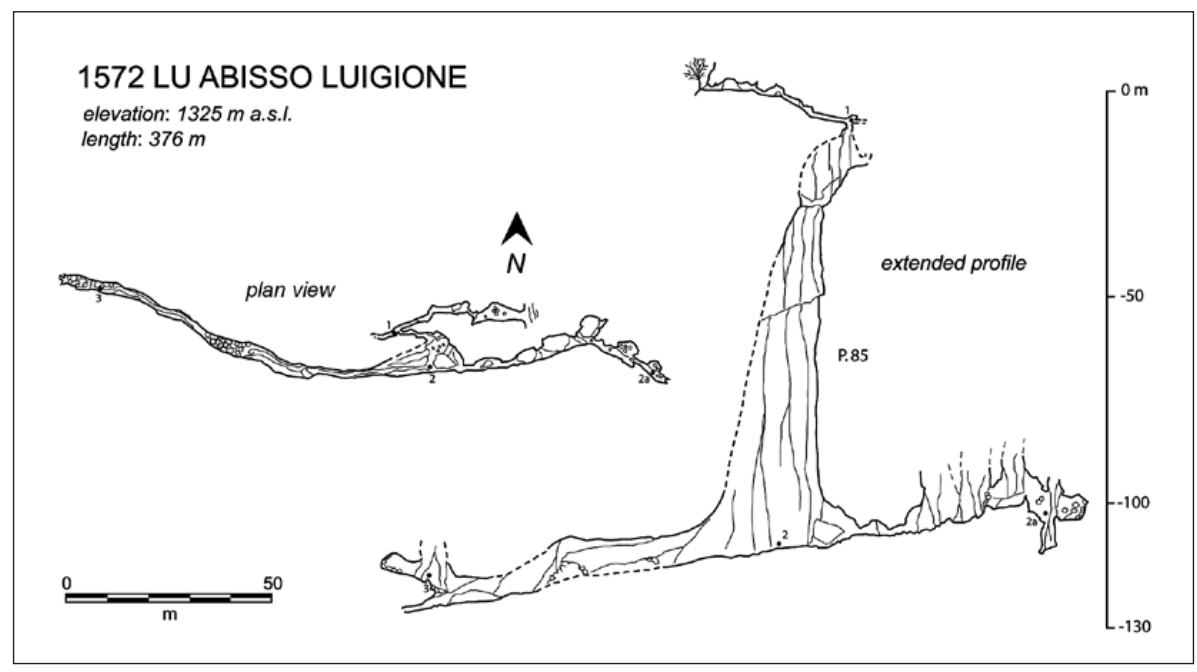

Fig. 9: Abisso Luigione, the deepest cave of the area (survey, lacking the upper part, by Gruppo Speleologico Paletnologico G. Chierici - Reggio Emilia).

Along the left steep side of the Fiume canyon some horizontal caves are found (Fig. 7): Tana della Guerra (264 T/LU), Caverna del Frate (288 T/LU), Tana delle Gracchie (289 T/LU) and Tana dei Pipistrelli (1766 T/LU), while the Tana di Magnano (162 T/LU; Fig. 8) is located at the end of the valley. At an altitude of $560 \mathrm{~m}$ asl, in connection with the local karst water table, is the Pollone di Magnano karst spring, which is fed by the Pania di Corfino area.

Almost all horizontal caves are presently perched above modern valley bottoms, and all were clearly intercepted by the downcutting of the rivers. An important element is the presence of "exotic" arenaceous pebbles belonging to the Macigno Formation, because their presence inside the caves is not compatible with the current or recent hydro-morphological setting.

At higher altitudes and mainly located on the summit erosional surfaces, caves are for the most part formed due to percolation and have a vertical profile. Their morphological features are often compatible with the present hydrogeological conditions, and they have no evidence of having functioned as a sink in the past. The deepest vertical cave is the Abisso Luigione (1572 T/LU), reaching $200 \mathrm{~m}$ in depth (Fig. 9).

\section{BACKGROUND AND METHODS}

The development of a cave is strongly and rapidly affected by the lowering of the local base level, which is usually related to the incision rate of surface streams. If the local base level remains stable, cave systems form a complex and hierarchical network of epiphreatic tubes just above the altitude of springs (Palmer 1987; Ford \& Williams 2007). For this reason, when a litho-structural control can be excluded, the occurrence of extensive horizontal conduits in a narrow altitude range usually indicates a base level standstill. Conversely, when a rapid lowering of base level occurs, there is only the vadose deepening of underground drainage. If the water table remains fairly stable or when a slow incision occurs, tubular passages can evolve to low gradient canyons characterized by erosional forms and sometimes containing alluvial sediments (De Waele \& Piccini 2008).

In general, a phreatic speleogenetic phase can be related with a base level lying above or at the same altitude as the conduits, while a vadose phase needs a base level necessarily below the elevation of caves.

In order to distinguish vadose passages from epiphreatic and phreatic ones, all the cave maps were morphometrically analyzed and epi-phreatic passages were classified in $20 \mathrm{~m}$ elevation intervals and shown on a bar graph (Fig. 10). The major caves were directly investigated to better describe their morphological features and their in-fillings.

A comparison between orography and the altimetric distribution of cave passages is often very useful to understand the evolutionary phases of a karst system, (Piccini 1998; Piccini et al. 2003; Mayer et al. 2003; Anthony \& Granger 2007). For this reason, a geomorphological survey of the whole area was performed by aerial photo interpretation and by field surveys. All geomorphological elements were mapped and georeferenced by GIS software (ArcGis ${ }^{\oplus}$ by ESRI). Furthermore, a DEM 


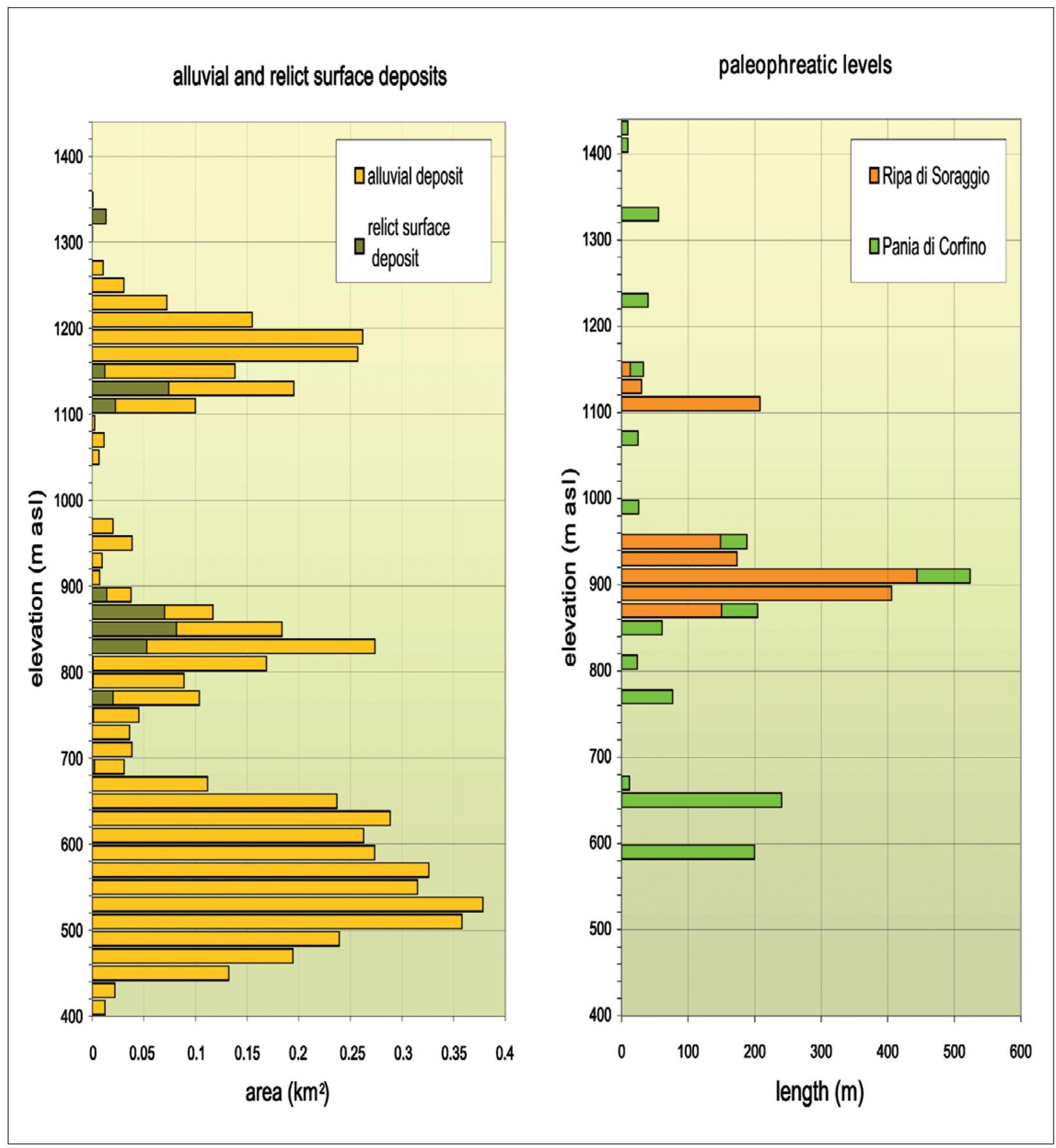

Fig. 10: Comparison between the altimetric distribution of alluvial and relict surface deposits (left) and paleo epiphreatic and phreatic levels (right) in Soraggio and Corfino areas.

was created from 1:10,000 cartographic vector data of Regione Toscana, resulting in a grid of $10 \times 10 \mathrm{~m}$ cells. The morphometric analysis of the DEM has allowed the extraction of the slope gradient and of the altimetric distribution of ancient alluvial and colluvial deposits. This last objective was obtained through the merging of a detailed geological map $(1: 10,000)$ with the elevation grid.
Generic low-gradient surfaces on alluvial deposits were delimited through the DEM analysis and investigated through aerial photos and directly in the field. Some of these flat surfaces have been interpreted as remnants of degraded terraces and compared with the elevation of epi-phreatic caves (Fig. 10). 


\section{RESULTS}

Many of the longest caves of the Soraggio-Corfino area show phreatic and epiphreatic passages located at much higher altitude (up to $500 \mathrm{~m}$ above) with respect to the present base level of karst aquifers, which is located at $720 \mathrm{~m}$ asl in the Soraggio valley and at $560 \mathrm{~m}$ asl in the Fiume valley. Comparing the vertical distribution of phreatic and epiphreatic caves with the alluvial deposits and relict-surface deposits, some relationships result (Fig. 10).

At the Soraggio area, the uppermost epiphreatic level is preserved in the Antro del Fauno cave at an elevation of about $1000 \mathrm{~m}$. This cave consists of a tubular passage that was later entrenched by vadose incision, forming a typical "key-hole" cross-section, and then filled with alluvial sediments. These morphological features suggest a standstill of base level and/or possibly an aggradation phase, which could be related to the ancient alluvial deposits located between 1120 and $1220 \mathrm{~m}$ asl (Fig. 11).

The second paleo-phreatic level ranges from 850 to $940 \mathrm{~m}$ asl and is preserved mainly in the Porta della Ripa and Fate di Soraggio caves. The first one was formed firstly by a rising artesian flow, suggesting that during its formation, the local base level was at more than $940 \mathrm{~m}$ asl. Later the upper part of the cave was abandoned, whereas a second phreatic phase formed a level of tunnels at about $900 \mathrm{~m}$. This second level shows a successive, but
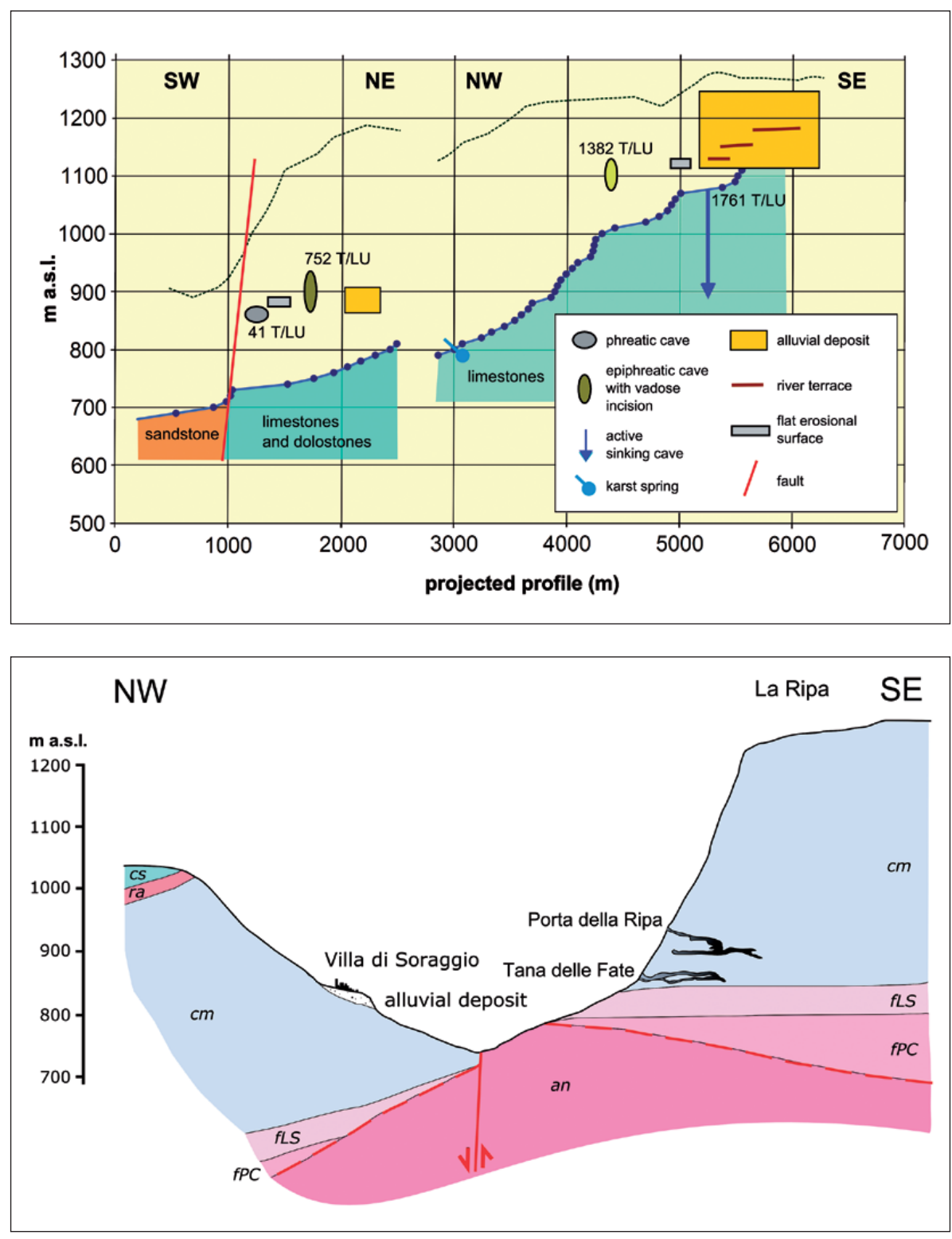

Fig. 11: Compound projected profile along the Serchio di Soraggio and Rio Rimonio streams, showing the present altimetric location of caves and fluvial landforms. The step of the profile along the fault is probably due to differential erosion between limestone and sandstone.

Fig. 12: Sketch profiles of the Serchio di Soraggio middle section, showing the present altimetric relationships between caves and fluvial deposits. Topographic profile is indicative and out of scale in the horizontal axis. Formations: an) Anidriti di Burano; fPC) Formazione della Pania di Corfino; fLS) Formazione della Spezia; cm) Calcare Massiccio; ra) Rosso Ammonitico; cs) Calcare Selcifero di Limano. 


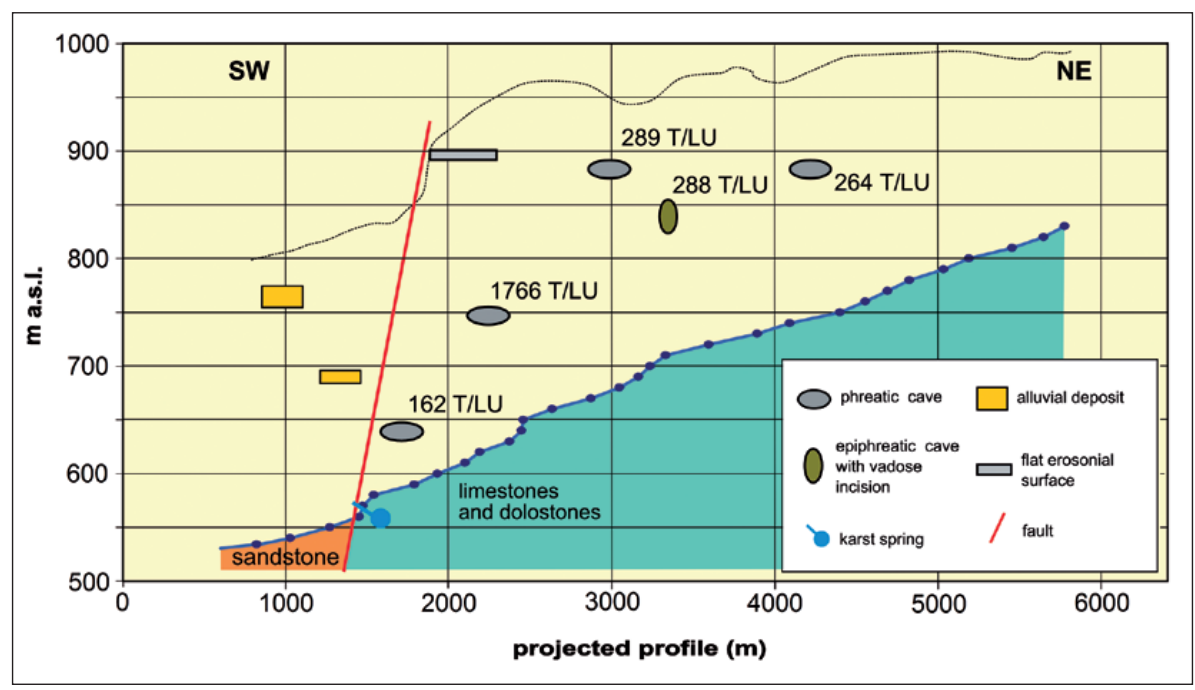

Fig. 13: NW-SE projected profile of the Fiume river, showing the present altimetric location of caves and fluvial landforms. The step of the profile along the fault is apparent and due to a stream path parallel to the fault line.

not very relevant, entrenching phase under vadose conditions. A few tens of meters below, the Fate di Soraggio cave consists of a horizontal maze network of epiphreatic tubes, which do not show significant reworking under vadose conditions. This second cave level can be related to the Soraggio alluvial deposit, which occurs between $820 \mathrm{~m}$ and $850 \mathrm{~m}$ asl (Fig. 12).

In the Fiume valley there are no well-evident paleo-phreatic levels. Small phreatic caves occur at about 880, 840, 880 and $750 \mathrm{~m}$ asl, whereas the longest phreatic tubes are preserved in the Tana di Magnano cave at $630-640 \mathrm{~m}$ asl (Fig. 13). Taking into account that the water table in karst systems usually has a small gradient, the phreatic phase at $840-880 \mathrm{~m}$ asl could be related to some benched flat erosional surfaces at about $900 \mathrm{~m}$ asl, whereas the phreatic cave at $750 \mathrm{~m}$ (Tana dei Pipistrelli) could be related to the paleo-valley deposits located at 760-780 m near the Corfino Village.

The more recent generation of phreatic cave (Tana di Magnano) is located at $640 \mathrm{~m}$ asl, only $80 \mathrm{~m}$ above the current karst base level, and can be compared to terraced deposits placed $40 \mathrm{~m}$ above, assuming for this cave an origin in deep phreatic conditions due to the lack of any epiphreatic forms. At any rate, it must be considered that in this sector the alluvial deposits are out of the carbonate area (see Figs. 1 \& 13), and so they might have been displaced by the NW-SE oriented faults bounding the Mesozoic outcrops.

\section{DISCUSSION}

\section{CAVE AND RIVER NETWORK EVOLUTION OF THE SORAGGIO VALLEY}

The Serchio di Soraggio follows an important fault line, and it probably downcut into more erodible formations (Scisti Policromi shales), which here have a larger thickness, first and for a longer period than the surrounding valleys. Due to this different incision rate, the karst groundwater drainage was diverted toward the Soraggio valley, and underground captures could have affected the Fiume a Corte through sinking caves (Fig. 14).

One of these ancient diversion caves is the Antro del Fauno, a branch of which is completely filled with coarse alluvial sediments (Fig. 15). The Antro del Fauno was formed as an epiphreatic conduit when the base level was at 1000-1100 m asl. The downcutting of the Soraggio valley lowered the hydrological base level and conse- quently caused the vadose entrenchment of the conduit, resulting in the formation of an underground canyon (Fig. 16). Afterwards, the pebble deposit invaded the cave, entering through swallow holes located on the Ripa di Soraggio. The sandstone pebbles testify to the underground capture of a surface stream, which was the paleo Fiume a Corte or one of its tributaries. Successively, and as a consequence of the downcutting of the Soraggio river, the cave in-fills were removed again and the cave was partially emptied. Finally, the cave was completely deactivated.

The fast downcutting of the Serchio di Soraggio caused the surface capture of the paleo Fiume a Corte first and of the paleo Rio Rimonio, by a left tributary, with the formation of the present-day deep gorge. Due to the downcutting of this secondary valley, the swallow 


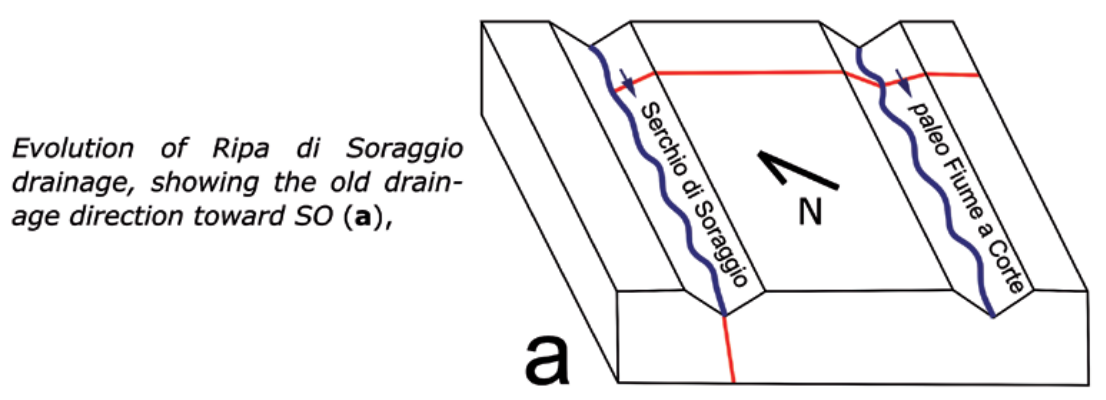

Fig. 14: Evolution steps showing the underground (b) and surface (c) deviations of the Fiume a Corte towards the Serchio di Soraggio.

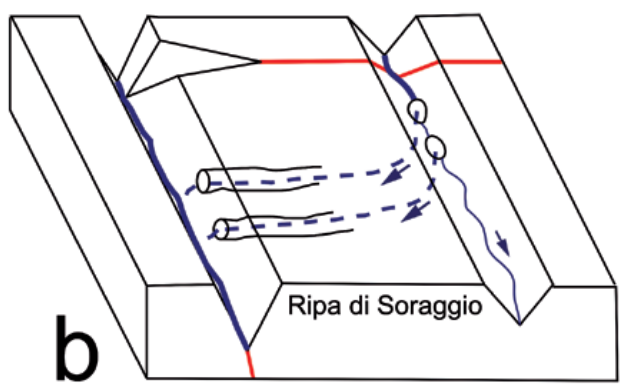

the subterranean cut-off (b),

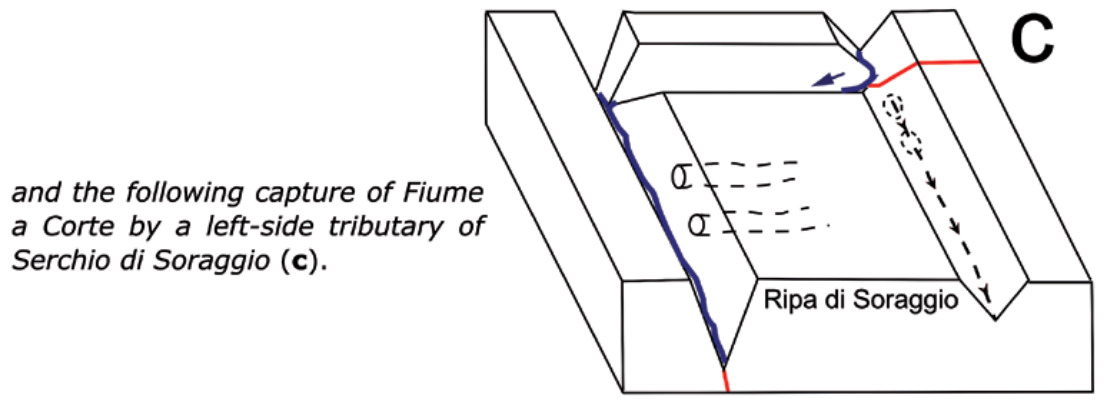

ca. $2 \mathrm{~km}$

caves along the paleo Fiume a Corte were de-activated (Fig. 14).

The alluvial deposit of Villa Soraggio, between 820 and $850 \mathrm{~m}$ asl, indicates a further stage of deposition, which stopped the incision of the valley and which could be related to the vadose enlargement of the lower passages in the Porta della Ripa cave and to the formation of the phreatic tunnels in the Tana delle Fate cave, placed just at this elevation range (see Fig. 12).

Now, it is important to consider the role of the NESW oriented fault, running along the Soraggio valley. If the fault had remained inactive after the formation of the deposit, the conduits of these caves were surely formed before the fluvial deposition phase, because their morphological features and their present elevation at 850$900 \mathrm{~m}$ indicate a higher base level. In other words, the vadose reworking of the Porta della Ripa could be thus correlated with the deposition of the Villa Soraggio fluvial terrace, because the vadose incision needs a base level located below the elevation of the cave. In this circumstance, the invasion by allogenic pebbles is probably due to swallow holes along the riverbed of the NW-SE oriented trunk of the present Rio Rimonio, during the capture of the upper catchment area of paleo Fiume a Corte (See Fig. 2).

Conversely, if the fault was significantly active after the formation of the caves, the formation of phreatic conduits in Porta della Ripa and Tana delle Fate could be coeval or successive to the deposition of the Soraggio alluvium. The elevation range (about $100 \mathrm{~m}$ ) between the phreatic conduits and the bed of terraced deposits seems to indicate the first explanation as more probable, even if an activity of the fault cannot be excluded.

\section{CAVE AND RIVER NETWORK EVOLUTION OF THE FIUME VALLEY}

Along the Fiume valley, several caves have been intercepted during the downcutting. Most of them seem 
to be formed under epiphreatic conditions and are located between $560 \mathrm{~m}$ (the present karst base level) and $1030 \mathrm{~m}$ asl, with a major development between 700 and $900 \mathrm{~m}$. At this elevation, alluvial deposits occur near the village of Corfino and are interpreted as an old river-

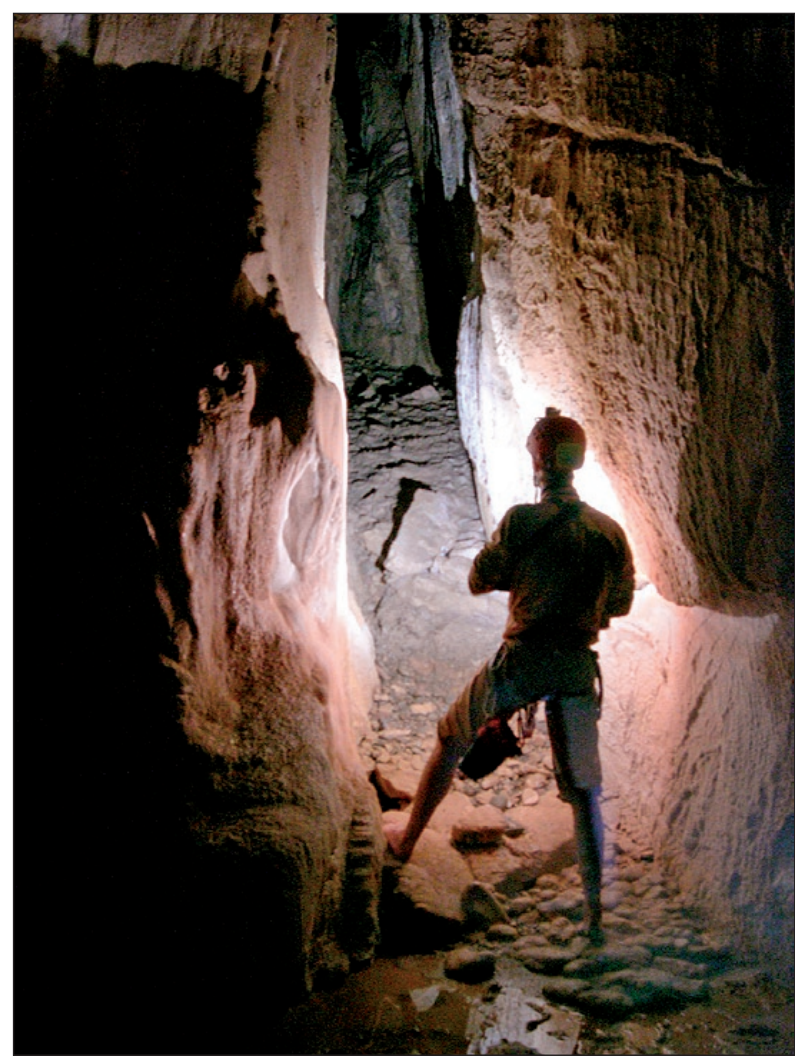

Fig. 15: Fluvial deposit with pebbles of sandstones (Macigno Fm.) filling a gorge inside the Antro del Fauno (Photo: L. Piccini).

bed of the Fiume valley located about $200 \mathrm{~m}$ above the present floor (Dallan et al. 1991). In this sector, a direct correlation between caves and deposits, based only on elevation, is problematic due to the possible activity of the Corfino fault and of the minor structures associated with it. The terrace deposits are in fact located just to the SW of the fault, so they are on the lowered block, whereas the caves are all located on the raised block (see Fig. 1).

The Fiume valley is intersected by faults and fractures, associated with the main Corfino fault, but we have no geological evidence of their activity during speleogenetic phases. In particular, some small caves, which developed along secondary faults, do not show any evidence of dislocation. Such situations are visible in the Tana delle Gracchie (Fig. 17) and in the Tana della Guerra, and suggest that the activity of these secondary discontinuities, and very likely of the main fault as well, has been of minor importance after the formation of the caves and during the valley's incision. At any rate, we cannot exclude that some tectonic movements could have affected the internal sectors of the carbonate massif after the formation of the higher caves.

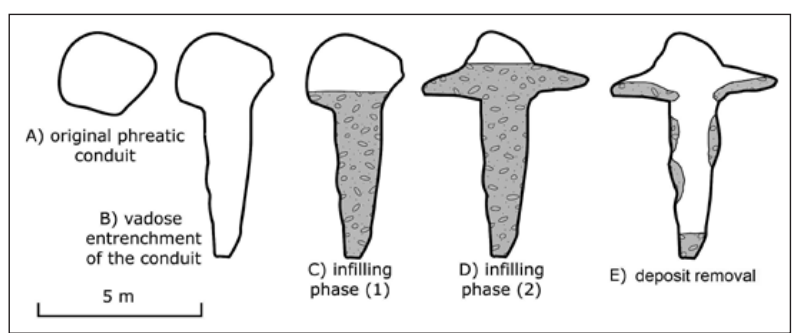

Fig. 16: Evolution steps of the main passage inside the Antro del Fauno, from a phreatic tube to a canyon, with different phases of filling and emptying.

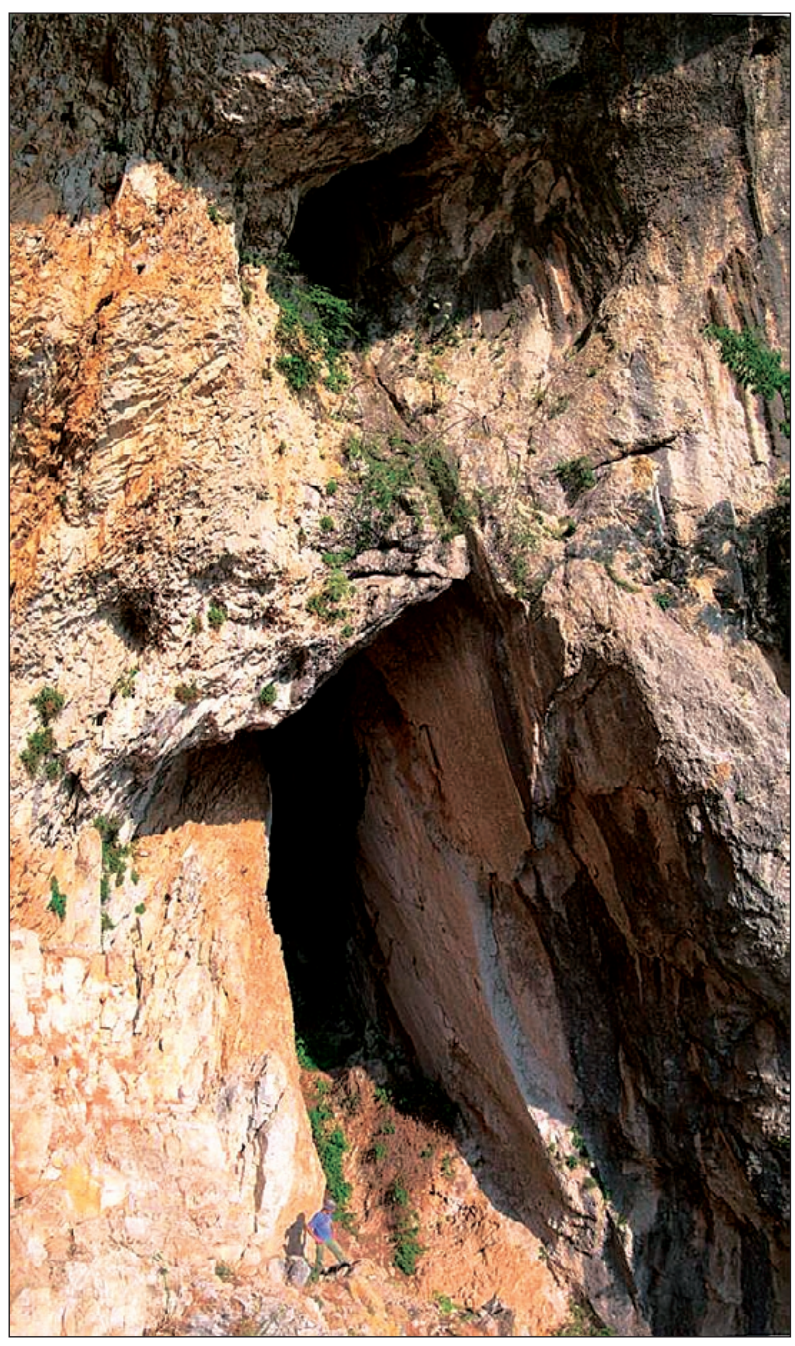

Fig. 17: The entrance of the Tana delle Gracchie, in the Fiume valley (Photo: L. Piccini). The cave is along a secondary fault but not displaced by tectonic activity. 


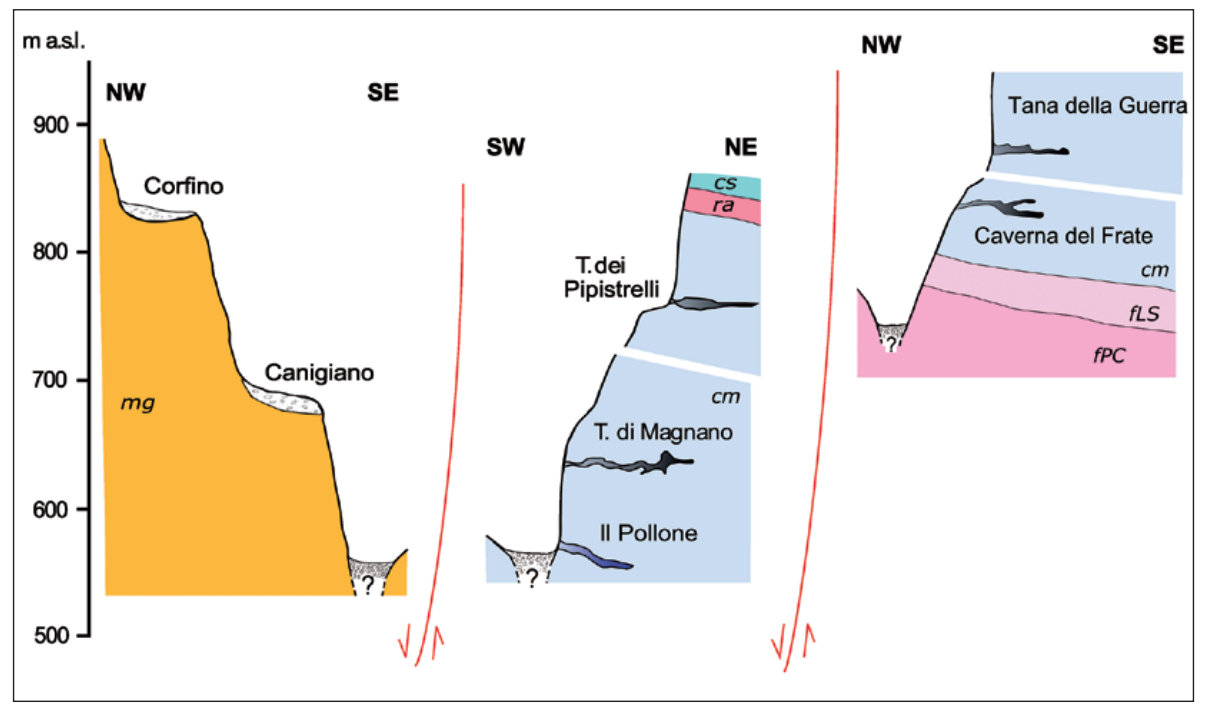

Fig. 18: Sketch compound profiles of the Fiume River canyon, showing the present altimetric relationships between caves and fluvial deposits. Topographic profiles are also indicative and out of scale in the horizontal axis. Formations codes as in Fig. 12.

If we take into account the position of the alluvial deposits and of the caves, we note that the elevation range between the old alluvial deposits and the present valley floor, in the lowered western sector of the fault, is similar to that existing between the river bed and some old phreatic caves (Caverna del Frate, Tana delle Gracchie and Tana della Guerra), in the uplifted sector east of the fault (Fig. 13). This suggests a similar incision rate in the two sectors of the river. Furthermore, the present base level is at $560 \mathrm{~m}$, corresponding to the Pollone di Magnano spring, while the relict caves and the paleovalley deposits are roughly around $830 \mathrm{~m}$ asl (Fig. 18). If we suppose that the karst base level was the same as deposition of the paleo-valley deposit, we can infer a low activity of the Corfino fault after the speleogenesis and the fluvial deposition stages. In short, all these elements suggest a condition of no substantial movement along the major faults, which border the Corfino-Soraggio carbonate massif, during and after speleogenesis. In this relatively stable framework, the formation of epi-phreatic levels was therefore due to different incision rates of the Fiume canyon not due to different uplift rates.

Another useful element for determining the evolution of this valley is the sandstone pebbles, which were deposited inside pre-existing caves during the progressive incision of the river. Fluviatile infills are found in the Tana della Guerra, Caverna del Frate, Tana delle Fate di Sassorosso, Tana di Magnano and the Tana dei Pipistrelli. These deposits consist of polymictic and unsorted conglomerates, which can be found also in some minor caves on the canyon slopes. These circumstances let us suppose an external provenance, instead of from upstream swallow holes as happened in the Soraggio caves.

\section{CONCLUSION}

Paleo-hydrographical reconstructions and altimetric correlations between epiphreatic-phreatic caves and alluvial deposits allow us to infer the main stages of karst development compared to the geomorphic history of this sector of the Northern Apennines during the MiddleLate Pleistocene.

The spatial distribution of caves do not fit the current morphological and hydrogeological setting, and so they must be considered as segments of old karst systems developed in a different hydro-morphological setting. Some caves, which are characterized by old epiphreatic passages containing reworked fluviatile sediments, have been related to the evolution of river drainage and to the progressive lowering of base level in the two major valleys: the Serchio of Soraggio and the Fiume rivers. The drainage geometry shows many captures, with a general NW and SE diversion trend from the carbonate outcrop (see Fig. 13). In particular, Fiume a Corte and Rio Rimonio show two NNW oriented (towards Serchio di Soraggio) elbows of river capture by a left-side tributary of the Serchio di Soraggio. Terraced alluvial deposits and some saddles trace the paleo-flow direction of these rivers (see Fig. 2). The capturing of surface drainage enhanced the downcutting of NW and SE peripheral streams, which 
received a larger quantity of water through karst springs due to the favorable morpho-structural situation. Finally, this strong downcutting led to a backward piracy of the allogenic catchments by surface tributaries and to the dewatering of caves.

As already suggested for the Barga depositional complex, we can refer to a simple model where fluvial deposition occurred mainly during cold stages and incision during warm stages (Coltorti et al. 2008). In such conditions, the discrete distribution of paleo-phreatic passages, which are found in the two major valleys (Soraggio and Fiume canyons) on a vertical range of a few hundred meters, suggests that the different stages are the middle-term responses to climatic changes, that is, to the alternation of cold and warm periods.
Chronological data on cave formation are scarce and only a rough timing of the speleogenesis stages can be inferred. Previous studies on the Tana dei Pipistrelli deposit (about $750 \mathrm{~m}$ asl and $120 \mathrm{~m}$ above the valley floor) describe an upper Holocene bed, with human tools, and a lower Pleistocene bed, with sandstone (Macigno) pebbles, and remnants of Ursus spelaeus, Marmota marmota and other small rodents (Lanza 1946; Azzaroli 1955). This fauna association is usually related to the Late Pleistocene glacial stages, but there are no sure elements for a more precise dating of the sediments, which are in any case, successive to the formation of the cave. Actually, only a rough attribution to Early-Middle Pleistocene of the upper cave levels can be inferred on the ground of present knowledge.

\section{ACKNOWLEDGEMENTS}

We wish to thank our friends of the Gruppo Speleologico Paletnologico "G. Chierici" of Reggio Emilia, particularly Claudio Catellani and Massimo Neviani, for useful discussions and for furnishing unpublished material. Thanks also to Carlo Bartolini and Milvio Fazzuoli for useful comments during the fieldwork and to Chris Loffredo for the revising of English syntax. Mauro Coltorti and France Šušteršič greatly improved the paper thanks to their careful and constructive revision.

\section{REFERENCES}

Anthony, D.M. \& D.E. Granger, 2007: A new chronology for the age of Appalachian erosional surfaces determined by cosmogenic nuclides in cave sediments.- Earth Surface Processes and Landforms, $32,874-887$.

Azzaroli, A., 1955: L’Appennino tosco-emiliano dal Passo di Pradarena al Passo delle Forbici e i nuclei mesozoici di Corfino e Soraggio.- Bollettino Società Geologica Italiana, 74, 1-72.

Bartolini, C., 2003: When did the Northern Apennine become a mountain chain?- Quaternary International, 101-102, 75-80.

Bartolini, C. \& M. Fazzuoli, 1997: Ruolo della tettonica e della morfoselezione nell'evoluzione dell'idrografia nel bacino del fiume Serchio.- Il Quaternario, 10, 417-426.

Catellani, C., Davoli, A. \& W. Formella, 2002: Trent'anni di attività del GSPGC in Toscana dalla Via Vandelli al mare.- In: Atti VII Congr. Federazione Speleologica Toscana, Gavorrano (GR), March 31 - April 1 2001, 49-71, Grosseto.
Catellani, C., Davoli, A., Formella, W., Franchi, M. \& M. Malvini, 1995: Le grotte della Ripa di Soraggio e della Pania di Corfino - parte prima.- Suppl. a Ipoantropo, Bollettino GSPGC-RE, pp. 12.

Coltorti, M., Pieruccini, P. \& M. Rustioni, 2008: The Barga Basin (Tuscany): A record of Plio-Pleistocene mountain building of the Northern Apennines, Italy.- Quaternary International, 189, 1, 56-70.

Dallan, L., Nardi, R., Puccinelli, A., D’Amato Avanzi, G. \& M. Trivellini, 1991: Valutazione del rischio da frana in Garfagnana e nella media valle del Serchio (LU). Carta geologica e della franosità degli elementi "Sillano", "Corfino", "Fosciandora" e "Coreglia" (scala 1:10.000).- Bollettino Società Geologica Italiana, 110, 245-272.

De Waele, J. \& L. Piccini, 2008: Speleogenesi e morfologia dei sistemi carsici in rocce carbonatiche.- In: Parise, M., Inguscio S. \& A. Marangella (eds.) Atti $45^{\circ}$ Corso CNSS-SSI "Geomorfologia carsica", Grottaglie, Bari, $2^{\text {nd }}-3^{\text {th }}$ February 2008, 23-74, Grottaglie. 
Fazzuoli, M., 1974: Caratteri sedimentologici del Calcare Massiccio nell'area della Pania di Corfino (Lucca).Bollettino Società Geologica Italiana, 93, 735-752.

Fazzuoli, M. \& A. Turi, 1981: Ricerche stratigrafiche, sedimentologiche e petrografiche sulla sequenza triassica della Pania di Corfino (Appennino Settentrionale).- Bollettino Società Geologica Italiana, 100, 541-553.

Fazzuoli, M., Ferrini, G., Pandeli, E. \& G. Sguazzoni, 1985: Le formazioni giurassico-mioceniche della Falda Toscana a nord dell'Arno: considerazioni sull'evoluzione sedimentaria.- Memorie Società Geologica Italiana, 30, 159-201.

Ford, D. C. \& P.W. Williams, 2007: Karst hydrogeology and geomorphology.- John Wiley \& Sons Ltd., pp.562, Chichester.

Lanza, B., 1946: Reperti paleontologici e paletnologici in due caverne dei dintorni di Sassorosso (Lucca).Historia Naturalis, 1, 89.

Mariannelli, G., 2006: Il fenomeno carsico dei nuclei mesozoici di Soraggio e Corfino.- Tesi di Laurea, Università di Firenze, pp. 93.
Mayer, L., Menichetti, M., Nesci, O. \& D. Savelli, 2003. Morphotectonic approach to the drainage analysis in the North Marche region, central Italy.- Quaternary International, 101-102, 157-167.

Palmer, A.N., 1987: Cave levels and their interpretation.The National Speleological Society Bulletin, 49, 5066.

Piccini, L., 1998: Evolution of karst in the Alpi Apuane (Italy): Relationships with the morphotectonic history.- Suppl. Geografia Fisica e Dinamica Quaternaria, 3,4, 21-31.

Piccini, L., Drysdale, R. \& H. Heijnis, 2003: Karst morphology and cave sediments as indicators of the uplift history in the Alpi Apuane (Tuscany, Italy).Quaternary International, 101-102, 219-227.

Puccinelli, A., 1987: Un esempio di tettonica recente nella val di Serchio: il sollevamento di Monte Perpoli.Atti Società Toscana Scienze Naturali, Memorie, serie A, 94, 105-117.

Quarina, L., 1910: Appunti di speleologia della Garfagnana. Stabilimento Tipografico A. Rosa, pp. 32, Castelnuovo Garfagnana. 